Review

\title{
Review on Development of High-Static-Low- Dynamic-Stiffness Seat Cushion Mattress for Vibration Control of Seating Suspension System
}

\author{
Linchuan Guo ${ }^{1}$, Xu Wang ${ }^{1, *(\mathbb{D})}$, Rang-Lin Fan ${ }^{2, *} \mathbb{C}$ and Fengrong $B i^{3, *}$ \\ 1 School of Engineering, RMIT University, Bundoora, VIC 3083, Australia; S3454089@student.rmit.edu.au \\ 2 School of Mechanical Engineering, University of Science and Technology Beijing, Beijing 100083, China \\ 3 School of Mechanical Engineering, Tianjin University, Tianjin 300072, China \\ * Correspondence: xu.wang@rmit.edu.au (X.W.); fanrl@ustb.edu.cn (R.-L.F.); fr_bi@tju.edu.cn (F.B.); \\ Tel./Fax: +03-9925-6028 (X.W.)
}

Received: 12 March 2020; Accepted: 11 April 2020; Published: 22 April 2020

\begin{abstract}
This review focuses on studying passive vibration isolation techniques and their applications. Advantages and disadvantages of different vibration isolation techniques will be compared in order to find an innovative method to reduce seating suspension system vibration and improve the ride comfort of vehicles' drivers. Quasi-zero stiffness (QZS) isolators of high-static-low-dynamic stiffness are found to have good application prospects in low-frequency vibration isolation. In order to improve the isolation performance of the seating suspension system, a specially made seat cushion will be studied where a quasi-zero stiffness (QZS) isolator such as a double-diamond isolator is selected as one of the cells/units/elements of the seat cushion mattress. The double-diamond isolator structure does not represent the whole seating suspension system. The transmissibility ratio of the double-diamond isolator is evaluated by analytical and simulation models and compared to that of a conventional linear spring isolator. Although the performance of the passive vibration isolation/control system is usually worse than that of the active or semi-active control system, the cost of the passive vibration isolation/control system is lower than that of the active and semi-active control system, and the relative simplicity of adding a vibration isolation cushion mattress in an existing passive seating suspension system makes it low in cost, easy to implement, and more attractive than the active and semi-active vibration control systems.
\end{abstract}

Keywords: passive suspension; seating suspension system; vibration control; drivers' health; ride comfort; high-static-low-dynamic-stiffness (HSLDS); quasi-zero stiffness (QZS)

\section{Introduction}

It is widely known that vibrations are always present in running vehicles. Vibration is a mechanical motion phenomenon where a mass point oscillates around the equilibrium point. It is the source that causes discomfort, which is extremely harmful to vehicle operators and passengers. Pathology studies have shown that vehicle driver exposure under low-frequency vibrations generates whole-body-vibration (WBV), which always results in various health concerns and consequences, such as tiredness, fatigue, motion sickness, and vertebrae diseases [1], an increased risk of certain cancers, digestive issues, and vision damage [2], lower back pain [3], impairment of balance [4], and reduction in the human body reaction time and effectiveness [5]. Various types of vehicles, including motorcycles, cars, trucks, and buses, are very often subjected to road surface unevenness-induced vibrations. Research shows that a vehicle driver usually experiences vibrations in a wide frequency range, particularly in the frequency range from 0 to $20 \mathrm{~Hz}$ [6]. In order to improve ride comfort, a good seating suspension isolation system is essential. 
The seating suspension isolation system is a set of complex structures designed to isolate vibration from the vehicle floor to the human body. The main objective of the system is to reduce the vibration transmissibility between the source of vibrations and the seated human beings. The seating suspension isolation system reduces the effects of vibrations on the vehicle driver and passenger.

Over the decades, automotive engineers have been working hard to design a vehicle suspension system to reduce vibration transmitted to seated occupants and improve ride comfort. Although a variety of vibration control techniques have been developed to tackle vibration problems related to the seat structure design, which has achieved considerable progress [7], designing a good vehicle suspension system is still a challenging task for automotive engineers. For example, a lightweight structure is most commonly adopted in the seating suspension system design, because the lightweight structure contributes to reduced fuel consumptions and emissions. However, the lightweight structure design will naturally result in side effects of the degraded noise and vibration performance of the seating suspension system. Current design trends involve applying lightweight materials or structures in a more environmentally friendly design of the seating suspension system to achieve efficient vibration isolation effects and improve vehicle ride comfort. To be more specific, most frequently under constraints imposed on the frequency-dependent vibration attenuation efficiency, load capacity, installation and operation costs, and energy consumption all need to be considered in [8].

The vibration control system includes three types: Passive [9,10], semi-active [11], and active systems [12]. For an active vibration control system, unwanted vibrations are cancelled by an equal-in-amplitude but opposite-in-phase force that is generated by actuators and control algorithms [13] using sensors for vibration measurement. The active vibration control system usually has a better vibration reduction performance, but it needs external energy to power up the control system $[14,15]$. Figure 1 shows a prototype of an active vibration control system [16]. The semi-active vibration control system has worse vibration reduction performance than the active vibration control system [17]. However, the semi-active vibration control system would consume much less energy or power. Control units of the semi-active vibration control system would increase the weight and design complexity compared to the passive vibration control system [18]. A passive vibration control system has worse vibration reduction performance than the active and semi-active vibration control systems. However, the cost of the passive vibration control system is generally lower than that of the active and semi-active vibration control systems. The relative simplicity of the passive vibration control system makes it more reliable and robust [19].

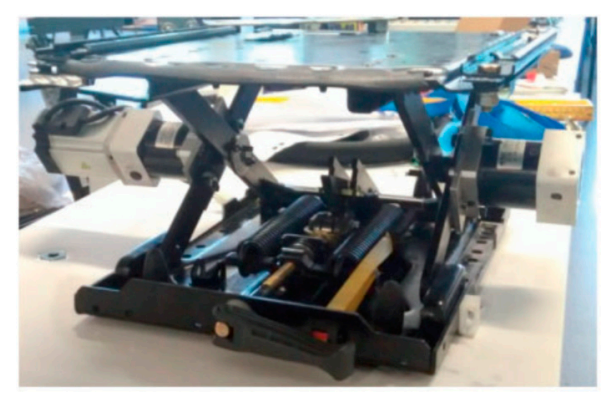

Figure 1. Active seating suspension system prototype [16].

The passive vibration control method is achieved by a mechanical connection that limits the vibration amplitude of the connected or coupled structures [20]. The mechanical connection dissipates or redirects the vibration energy before the energy is transmitted to the structures to be isolated. Figure 2 shows a prototype of the passive vibration control system [21]. The most common passive vibration control method is to move or tune the system-resonant frequencies away from the excitation frequencies. The system resonant frequency change mainly results from changing system stiffness and mass. The reduction in system resonance peak amplitude results from adding layers of damping materials. 


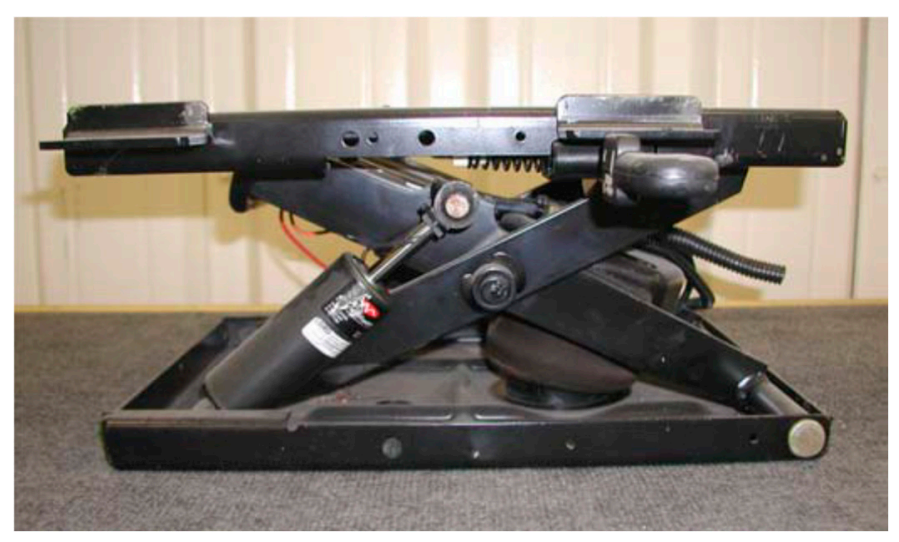

Figure 2. Passive seating suspension system prototype [19].

In some cases, electromechanical controls can sometimes be applied to optimize the system isolation, while the isolation mechanism itself is passive [22]. There are different isolation components adopted in passive vibration control systems such as fluids, springs, elastomers, and negative-stiffness structure components [23]. The spring is one of the most essential components, and it is placed between a source transmitting vibration and the receiver to be isolated. The spring isolates the impulse force above it and absorbs some vibration energy as it deforms [24]. In order to obtain better isolation performance, in addition to the spring isolation element, an elastomer is also used to achieve the damping effect. Elastomers are rubber-like materials that can absorb mechanical vibration energy through deformation. While the rubber has different deformation characteristics in different directions, the isolation performance would be different in different directions. Other isolators such as air, negative-stiffness, and magnetic structures are also sophisticated passive vibration control isolators [19].

Three types of the vibration control systems mentioned above aim to improve the ride comfort of the seating suspension system and ensure the health of the vehicle operator and passengers. The vehicle driver usually feels uncomfortable vibration in the low-frequency range from 2 to $8 \mathrm{~Hz}$, as the vibration is more likely to affect work efficiency [25]. Zhang et al. studied the comfort and ergonomics of seating suspension systems from several different perspectives in 1992 [26]. Several methods including electromyography, intervertebral disc pressure measurement [27], vibration transmissibility [28], pressure distribution at the occupant's seat interface [29,30], and microclimate at the occupant's seat interface [31] have been adopted to quantify ride comfort. As the research on the ride comfort of seating suspension systems goes further, new concepts and methods will be found. Low-frequency excitation generates whole-body-vibration (WBV), which affects all parts of the human body [32]. Multiple vibration transmission directions through a vehicle seat occupant are given in Figure 3 [33]. It clearly shows that the three translational vibrations are along the $x, y$, and $z$ axes and the three rotational vibrations are marked as roll, pitch, and yaw around the $x, y$ and $z$ axes, respectively. Several international industrial standards and safety manuals have been given to define a criterion for assessing the vibration dosage [33], which includes The Australian Standards AS-2670 [34], International Standards ISO-2631 [35], and British Standards BS ISO-2631 [36]. Several factors are adopted to evaluate the dosage of WBV.

Different vibration isolation systems have been designed and developed by different researchers in the past and will be introduced and illustrated in the following sections. 


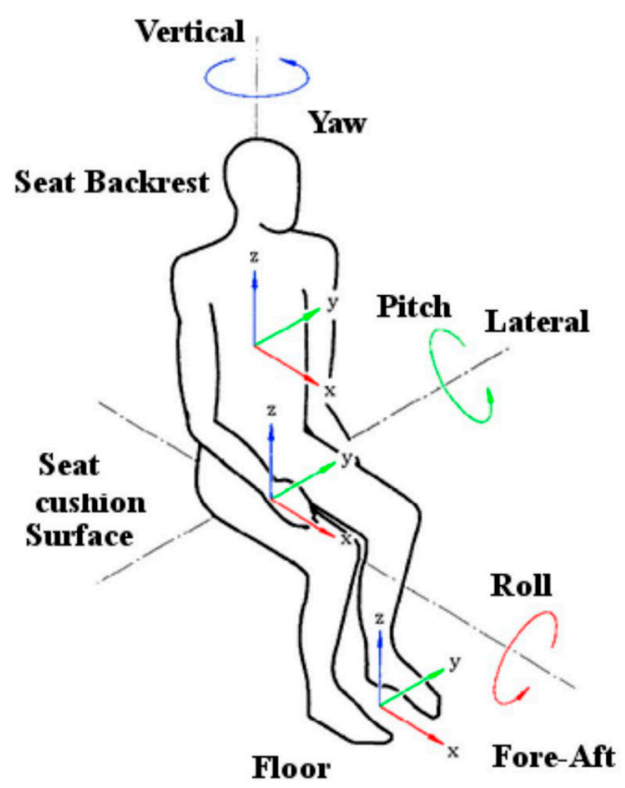

Figure 3. Vibration transmission directions through a vehicle seat occupant [33].

\section{Passive Vibration Isolation Designs}

Most of the seating suspension systems use 1- Degrees of freedom(DOF) vibration isolators that only reduce vibration in the vertical direction. However, the driver and passenger receive the vibrations transmitted from multiple directions. Therefore, a seating suspension system capable of attenuating vibration from multiple degrees of freedom is desired. In order to solve these issues, many research studies have been conducted on multi-degree-of-freedom vibration isolation, especially on 6-DOF vibration isolation. Two most significant aspects for the design of vibration isolators are highly effective vibration isolation and large loading capacity. In conventional passive isolation design, the mechanism supporting the preload has linear stiffness, a trade-off that is unavoidable between the vibration isolation efficiency and loading capacity [37]. The deflection in the resilient support structure of the isolator can generate a force to support the preload. Thus, a large stiffness is required to avoid excessive deflection. In contrast, low stiffness coupling helps to reduce the vibration transmissibility and the resonant frequency of the isolation system. However, mechanical coupling with a low stiffness will decrease the loading capacity of the system, which is disadvantageous in the seating suspension systems that require high loading capacity to support the weight of the driver and passenger. The high static stiffness and low dynamic stiffness are ideal for a vibration isolation system, which is a typical nonlinear stiffness characteristic. The property of the high static and low dynamic stiffness is called quasi-zero-stiffness (QZS) $[38,39]$. However, strong nonlinearity could induce the bifurcation phenomenon (e.g., jumping) in the existing QZS systems. Increasing the damping of the system could effectively reduce the jumping phenomenon.

Le and Ahn [40] proposed a negative-stiffness structure (NSS) for low-frequency passive vibration isolation. The possibility of using air springs and shock absorbers to improve the vibration isolation performance of the seating suspension system was studied by Maciejewski et al. [41]. A seating suspension system has been designed by Holtz and Van Niekerk for typical articulated or rigid frame dump trucks, which have air springs and auxiliary volumes [42]. In addition, the passive vibration isolation of QZS devices and structures has been studied [43,44]. Zhu et al. [45] developed a novel 6-DOF isolator in 2015, using magnetic levitation to provide the QZS vibration isolation in the vertical direction and zero stiffness in the other five directions. Wu et al. [46] proposed a 6-DOF isolator in 2016 based on the Stewart platform configuration but used the novel biological inspiration X-shaped [47] structure as legs, rather than the active actuator/damper in the traditional Stewart platform. Zhou et al. [48] in 2017 presented a procedure or method for creating a 6-DOF QZS vibration 
isolation platform by using QZS struts, which is the latest development work of the 6-DOF vibration isolator proposed. Le et al. [49] proposed a low-frequency vibration isolation system with an NSS for a driver's seat where the NSS can be used to reduce the dynamic response of the isolated equipment while the load-carrying capacity is maintained. A vibration isolator with the QZS property in three different directions was proposed by Sun et al. [50]. Chao-Chieh [51] proposed vibration isolators of the QZS characteristics. The proposed isolator consists of two adjustment mechanisms, which are the vertical adjustment and the lateral adjustment. The lateral adjustment is designed to match the geometric ratio with the stiffness ratio so that zero stiffness can be achieved under imperfect conditions. Instead of using coil springs, the isolator adopts specially designed planar springs. A planar spring can be easily redesigned to achieve an arbitrary stiffness. The flat cross-section of the spring makes the assembled isolator very compact. The vertical adjustment is used to maintain the equilibrium position so that the isolation applies to different loads.

Recently, many vibration isolators of the QZS characteristics have been proposed to overcome the drawbacks of traditional passive linear isolators [51-54]. Specifically, a QZS isolator has two advantages. One is being able to attenuate the transmission of the low-frequency vibrations, and the other is possessing high static stiffness to prevent large static deflections [55]. The NSS is the vital component in the QZS isolator [56]. There exist several formulas to realize a negative-stiffness structure mechanism. The oblique-spring mechanism was the earliest form [57] and was often utilized as a theoretical model for performance evaluation of the QZS isolator. Moreover, an oblique-spring could be bulky. Changing it into a planar or oblique link-connecting horizontal spring could avoid the possible bulk. Other ways for achieving the negative stiffness include the scissor-like structures [50], cam-roller spring mechanism (CRSM) [58], magnetic springs, and bi-stable structures [59]. All these methods outlined above indicate that the QZS isolator could be an effective system to isolate the low-frequency vibration. There are different approaches proposed to achieve QZS characteristics. A summary of different types of isolators is listed in Table 1 below.

As shown in Table 1, Xiuting [47] presented a 6-DOF passive vibration isolator with the Stewart platform and X-shaped support legs. It is a simple design due to its passive vibration isolation approach. This is a very flexible and versatile scissor-like structure, which can be independent of or combined with other vibration isolators, to provide damping and stiffness as a passive or semi-active isolator. Furthermore, a prototype, as shown in Figure 4, does not contain any active or semi-active actuator devices. Flexible structure size is applicable for different application situations and can also provide good vibration isolation performance. The peak amplitude result of the displacement transmissibility is 4 at $0.35 \mathrm{~Hz}$.

However, there are some limitations, such as the load capacity of the system, which is primarily dependent on the ratio of the height of the system over the length of the support legs $\mathrm{H} / \mathrm{h}$ and dependent on the stiffness of the spring, as the seat suspension system will have to support the load of the driver and seat weight. One of the essential parameters to be considered is the load capacity of the system that was not discussed clearly in the paper [46]. 
Table 1. Summary of different types of passive vehicle seat isolators.

\begin{tabular}{|c|c|c|c|c|c|c|}
\hline Type of Structure & Geometry & Key Features and Novelty & Advantage & Disadvantage & Performance Criterion & Performance \\
\hline $\begin{array}{l}\text { (6-DOF) X-shaped } \\
\text { support legs } \\
\text { quasi-zero-stiffness (QZS) } \\
\text { Stewart platform isolator } \\
\text { [38] }\end{array}$ & & $\begin{array}{l}\text { (1) Three layers; } \\
\text { (2) Each layer consists of connecting } \\
\text { rods and corresponding rotating joints. } \\
\text { (3) Support joints of the left bottom and } \\
\text { top layer sliding along horizontal tracks. } \\
\text { (4) Additional springs for extra stiffness. } \\
\text { (5) High--static-low-dynamic stiffness } \\
\text { (6) Double-diamond isolator structure in } \\
\text { place of X-shape structure. }\end{array}$ & $\begin{array}{l}\text { (1) A very flexible and versatile } \\
\text { scissor-like structure. } \\
\text { (2) It can be independent of or } \\
\text { combined with other vibration } \\
\text { isolators, to provide damping and } \\
\text { stiffness as the passive or } \\
\text { semi-active isolator. } \\
\text { (3) Flexible structure size for } \\
\text { different application situations. } \\
\text { (4) Good vibration isolation } \\
\text { performance. }\end{array}$ & $\begin{array}{l}\text { (1) Complex structure } \\
\text { and many components. }\end{array}$ & $\begin{array}{l}\text { Displacement } \\
\text { transmissibility } \\
\text { Equivalent stiffness }\end{array}$ & $\begin{array}{l}\text { The peak values of the } \\
\text { transmissibility ratios of } \\
\text { the mass-spring-damper } \\
\text { vibration isolator (MSD-VI), } \\
\text { scissor-like structure } \\
\text { vibration isolator (SLS-VI), } \\
\text { and quasi-zero-stiffness } \\
\text { vibration isolator (QZS-VI) } \\
\text { are 20, 8, and 4, respectively }\end{array}$ \\
\hline $\begin{array}{l}\text { (6-DOF) Stewart platform } \\
\text { with } \\
\text { high-static-low-dynamic } \\
\text { stiffness (HSLDS) passive } \\
\text { vibration isolator [60] }\end{array}$ & & $\begin{array}{l}\text { (1) Both the inner magnet and the outer } \\
\text { magnet are composed of several tile } \\
\text { magnets that are magnetized uniformly } \\
\text { along the radial direction. } \\
\text { (2) The inner magnet and the outer } \\
\text { magnet are in a repulsive configuration. } \\
\text { (3) The configuration is unstable in the } \\
\text { axial direction and can produce negative } \\
\text { stiffness. }\end{array}$ & $\begin{array}{l}\text { (1) Stewart platform can have } \\
\text { lower resonance frequencies } \\
\text { (2) Compact configuration of the } \\
\text { presented negative-stiffness } \\
\text { magnetic spring (NSMS). }\end{array}$ & $\begin{array}{l}\text { (1) Complex structure } \\
\text { and many components. } \\
\text { (2) High cost }\end{array}$ & $\begin{array}{l}\text { Displacement } \\
\text { transmissibility } \\
\text { Force transmissibility }\end{array}$ & $\begin{array}{l}\text { Compare to the system } \\
\text { without negative stiffness } \\
\text { magnetic spring, } \\
\text { frequency-sweeping results } \\
\text { is improved. }\end{array}$ \\
\hline $\begin{array}{l}\text { (6-DOF) Pyramidal } \\
\text { 3-quasi-zero-stiffness } \\
\text { (QZS) strut isolator [61] }\end{array}$ & & $\begin{array}{l}\text { (1) Four pyramidal 3-QZS-strut isolators } \\
\text { hold the platform } \\
\text { (2) Four pyramidal 3-QZS-struts are } \\
\text { identical to each other } \\
\text { (3) The vertical inclination angles are the } \\
\text { same at the static equilibrium } \\
\text { (4) Both the platform and machine are } \\
\text { mounted rigidly and located } \\
\text { symmetrically. }\end{array}$ & $\begin{array}{l}\text { (1) The proposed isolator has the } \\
\text { QZS characteristics in all six DOFs } \\
\text { (2) The QZS struts provided good } \\
\text { vibration isolation effectiveness } \\
\text { (3) Broadened the bandwidth of } \\
\text { vibration isolation into } \\
\text { lower-frequency } \\
\text { (4) jumping phenomenon reduced }\end{array}$ & $\begin{array}{l}\text { (1) Complex structure } \\
\text { and many components. } \\
\text { (2) High cost }\end{array}$ & Force transmissibility & $\begin{array}{l}\text { Natural frequency } \Omega_{x}=\Omega_{y} \\
=0.4082 \\
\Omega_{z}=1\end{array}$ \\
\hline $\begin{array}{l}\text { (3-DOF) Multi-direction } \\
\text { quasi-zero-stiffness } \\
\text { (MSQZS) vibration } \\
\text { isolator [49] }\end{array}$ & & $\begin{array}{l}\text { (1) Four } n \text {-layer scissor-like structures } \\
\text { assembled symmetrically } \\
\text { (2) Linear spring and damper are used in } \\
\text { the vertical direction } \\
\text { (3) Isolation object connected with four } \\
\text { scissor-like structures and linear spring } \\
\text { and damper }\end{array}$ & $\begin{array}{l}\text { (1) Excellent vibration isolation in } \\
\text { three directions simultaneously } \\
\text { (2) Adjustable structural } \\
\text { parameters in the QZS system with } \\
\text { scissors-like structure (SLS) }\end{array}$ & (1) Complex structure & $\begin{array}{l}\text { Displacement } \\
\text { transmissibility }\end{array}$ & $\begin{array}{l}\text { Compare to multi-direction } \\
\text { quasi-zero-stiffness } \\
\text { displacement } \\
\text { transmissibility, reduces } \\
\text { from } 11.5 \text { to } 0.5 .\end{array}$ \\
\hline
\end{tabular}


Table 1. Cont.

\begin{tabular}{|c|c|c|c|c|c|c|}
\hline Type of Structure & Geometry & Key Features and Novelty & Advantage & Disadvantage & Performance Criterion & Performance \\
\hline $\begin{array}{l}\text { (3-DOF) } \\
\text { High-static-low-dynamic } \\
\text { stiffness (HSLDS) struts } \\
\text { and spatial pendulum } \\
\text { passive isolator [62] }\end{array}$ & HsLDS isohoror I & $\begin{array}{l}\text { (1) The isolator composed of two HSLDS } \\
\text { struts, preload } m \text {, three spatial ball } \\
\text { hinges, and two massless rods. } \\
\text { (2) Without external excitation, the } \\
\text { isolator would stay at a static } \\
\text { equilibrium position } \\
\text { (3) The length of two massless rods is } l \text {. } \\
\text { (4) Payload } m \text { absolute motion is } z_{1} \text {, and } \\
\text { two horizontal directions are } x_{1} \text { and } y_{1} \text {. } \\
\text { (5) Two HSLDS struts are identical and } \\
\text { symmetrically fixed on the ground. } \\
\text { (6) HSLDS struts with magnetic negative } \\
\text { stiffness spring (MNSS) and spiral } \\
\text { flexure spring (SFS) }\end{array}$ & $\begin{array}{l}\text { (1) High-static-low-dynamic } \\
\text { stiffness in the vertical direction } \\
\text { and quasi-zero stiffness in two } \\
\text { horizontal directions } \\
\text { (2) Expanded low-frequency } \\
\text { isolation bandwidth in each } \\
\text { direction } \\
\text { (3) No resonance phenomenon } \\
\text { occurring in two horizontal } \\
\text { directions }\end{array}$ & $\begin{array}{l}\text { (1) Complex structure } \\
\text { and many components. } \\
\text { (2) High cost } \\
\text { (3) Large packaging } \\
\text { space. }\end{array}$ & $\begin{array}{l}\text { Displacement } \\
\text { transmissibility }\end{array}$ & $\begin{array}{l}\text { Except for the small rise in } \\
\text { the range from } 5 \text { to } 12 \mathrm{~Hz} \text {, } \\
\text { displacement } \\
\text { transmissibility in } x \text { and } y \\
\text { directions are good. }\end{array}$ \\
\hline $\begin{array}{l}\text { (3-DOF) } \\
\text { High-static-low-dynamic } \\
\text { stiffness (HSLDS) } \\
\text { magnetic vibration } \\
\text { isolator system [63] }\end{array}$ & $\begin{array}{c}\text { upprmanen } \\
\text { ringen }\end{array}$ & $\begin{array}{l}\text { (1) The isolator combines a } \\
\text { positive-stiffness spring with a } \\
\text { negative-stiffness in parallel. } \\
\text { (2) A special device spiral flexure spring } \\
\text { (SFS) is applied to provide positive } \\
\text { stiffness } \\
\text { (3) A magnetic negative-stiffness spring } \\
\text { (MNSS) is applied to provide negative } \\
\text { magnetic stifffess (MNS) } \\
\text { (4) Positive stiffness and negative } \\
\text { stiffness cancel each other for reducing } \\
\text { the resonance frequency of the isolator. }\end{array}$ & $\begin{array}{l}\text { (1) Good load capacity under a } \\
\text { small static deformation } \\
\text { (2) Large and flattened magnitude } \\
\text { of MNS near the equilibrium } \\
\text { position } \\
\text { (3) Damping property is improved } \\
\text { considerably. }\end{array}$ & $\begin{array}{l}\text { (1) Complex structure } \\
\text { and many components. } \\
\text { (2) High cost }\end{array}$ & Vibration transmissibility & $\begin{array}{l}\text { Compare to the system } \\
\text { without magnetic } \\
\text { negative-stiffness spring, } \\
\text { the vibration } \\
\text { transmissibility has been } \\
\text { reduced by } 22.25 \text {. }\end{array}$ \\
\hline $\begin{array}{l}\text { (2-DOF) Torsion QZS } \\
\text { vibration isolator [58] }\end{array}$ & 尰 & $\begin{array}{l}\text { (1) Shafts connected two ends of the } \\
\text { isolator } \\
\text { (2) The right (7) and left (6) shaft } \\
\text { connector are connected } \\
\text { (3) The rubber is a linear vibration } \\
\text { isolator } \\
\text { (4) Four cylindrical cams (1) contact with } \\
\text { four rollers (2) } \\
\text { (5) Roller (2) is held by slider (4), and } \\
\text { sliders are supported by a spring (3) } \\
\text { (6) As for rolling contact, the friction } \\
\text { between the cylindrical cam (1) and the } \\
\text { roller (2) is neglected }\end{array}$ & $\begin{array}{l}\text { (1) The QZS isolator has a good } \\
\text { sensibility to a deviation of output } \\
\text { torque. }\end{array}$ & $\begin{array}{l}\text { (1) Limited application } \\
\text { range where the designed } \\
\text { transmission torque is } \\
\text { constant. } \\
\text { (2) Complex structure } \\
\text { and many components. }\end{array}$ & $\begin{array}{l}\text { Dimensionless } \\
\text { torque-torsion } \\
\text { Dimensionless stiffness }\end{array}$ & $\begin{array}{l}\text { Compare to linear system } \\
\text { torque transmissibility, } \\
\text { reduced from } 23 \text { to } 18\end{array}$ \\
\hline
\end{tabular}


Table 1. Cont.

\begin{tabular}{|c|c|c|c|c|c|c|}
\hline Type of Structure & Geometry & Key Features and Novelty & Advantage & Disadvantage & Performance Criterion & Performance \\
\hline $\begin{array}{l}\text { (2-DOF) } \\
\text { High-static-low-dynamic } \\
\text { stiffness (HSLDS) } \\
\text { vibration isolator } \\
\text { system [64] }\end{array}$ & renome & $\begin{array}{l}\text { (1) The mass } M \text { is connected to the base } \\
\text { through two horizontal springs and a } \\
\text { connecting bar and a vertical spring } \\
\text { (2) Horizontal springs are connected } \\
\text { between the base and two rollers, and } \\
\text { are able to slide in the horizontal } \\
\text { direction freely } \\
\text { (3) The connecting bar is linked between } \\
\text { the roller and mass at point } P \text {. Thus, the } \\
\text { mass can move vertically. }\end{array}$ & $\begin{array}{l}\text { (1) Good isolation performance in } \\
\text { low-frequency vibration and } \\
\text { micro-vibration isolation. } \\
\text { (2) By reduction in the stiffness in } \\
\text { the static equilibrium position and } \\
\text { by an increase in the dimensionless } \\
\text { spring deformation range. The } \\
\text { vibration isolation region has been } \\
\text { increased, and the force } \\
\text { transmissibility ratio has been } \\
\text { reduced. }\end{array}$ & $\begin{array}{l}\text { (1) Limited installation } \\
\text { space } \\
\text { (2) Limited maximum } \\
\text { vibration displacement } \\
\text { responses }\end{array}$ & $\begin{array}{l}\text { Dimensionless-displacement } \\
\text { and } \\
\text { force transmissibility } \\
\text { and } \\
\text { dimensionless stiffness }\end{array}$ & \\
\hline $\begin{array}{l}\text { (1-DOF) } \\
\text { Negative-stiffness } \\
\text { magnetic spring (NSMS) } \\
\text { vibration isolator } \\
\text { system [60] }\end{array}$ & & $\begin{array}{l}\text { (1) The structure contains a mechanical } \\
\text { spring in parallel with a } \\
\text { negative-stiffness magnetic spring } \\
\text { (NSMS). } \\
\text { (2) The isolated mass moves only in the } \\
\text { vertical direction. } \\
\text { (3) The NSMS is composed of two } \\
\text { opposite-direction ring permanent } \\
\text { magnets } \\
\text { (4) The outer magnet is fixed on the base, } \\
\text { and the inner magnet is fixed with mass } \\
m \text {. The mechanical spring is connected } \\
\text { between the inner magnet and base. }\end{array}$ & $\begin{array}{l}\text { (1) The proposed NSMS isolator } \\
\text { can effectively reduce the peak } \\
\text { transmissibility and resonance } \\
\text { frequency }\end{array}$ & $\begin{array}{l}\text { The jump-down } \\
\text { frequency would increase } \\
\text { under excessive base } \\
\text { excitation }\end{array}$ & $\begin{array}{l}\text { Displacement } \\
\text { transmissibility }\end{array}$ & $\begin{array}{l}\text { Compare to the system } \\
\text { without negative-stiffness } \\
\text { magnetic spring, the } \\
\text { displacement } \\
\text { transmissibility has } \\
\text { reduced from } 23 \text { to } 15 \text {. }\end{array}$ \\
\hline $\begin{array}{l}\text { Vibration isolator with } \\
\text { quasi-zero stiffness [42] }\end{array}$ & & $\begin{array}{l}d_{1} \text { represents the diameter of the inner } \\
\text { wall; } d_{2} \text { the diameter of the outer wall; } t \\
\text { the wall thickness; } \mathrm{s} \text { the height of the } \\
\text { outer wall; } \phi \text { the angle of the wall } \\
\text { inclination; } h_{s} \text { the height of the outer } \\
\text { wall; } t_{s} \text { the thickness of the outer wall; } F \\
\text { the load, and } x \text { the compression. }\end{array}$ & $\begin{array}{l}\text { (1) Low cost and high speed of } \\
\text { manufacture } \\
\text { (2) A low natural frequency, which } \\
\text { is excellent for vibration isolators }\end{array}$ & (1) Low load capacity & Natural frequency & $\begin{array}{l}\text { The natural frequency of } \\
\text { the vibration isolator with a } \\
\text { clamp is less than } 0.5 \text {. }\end{array}$ \\
\hline
\end{tabular}



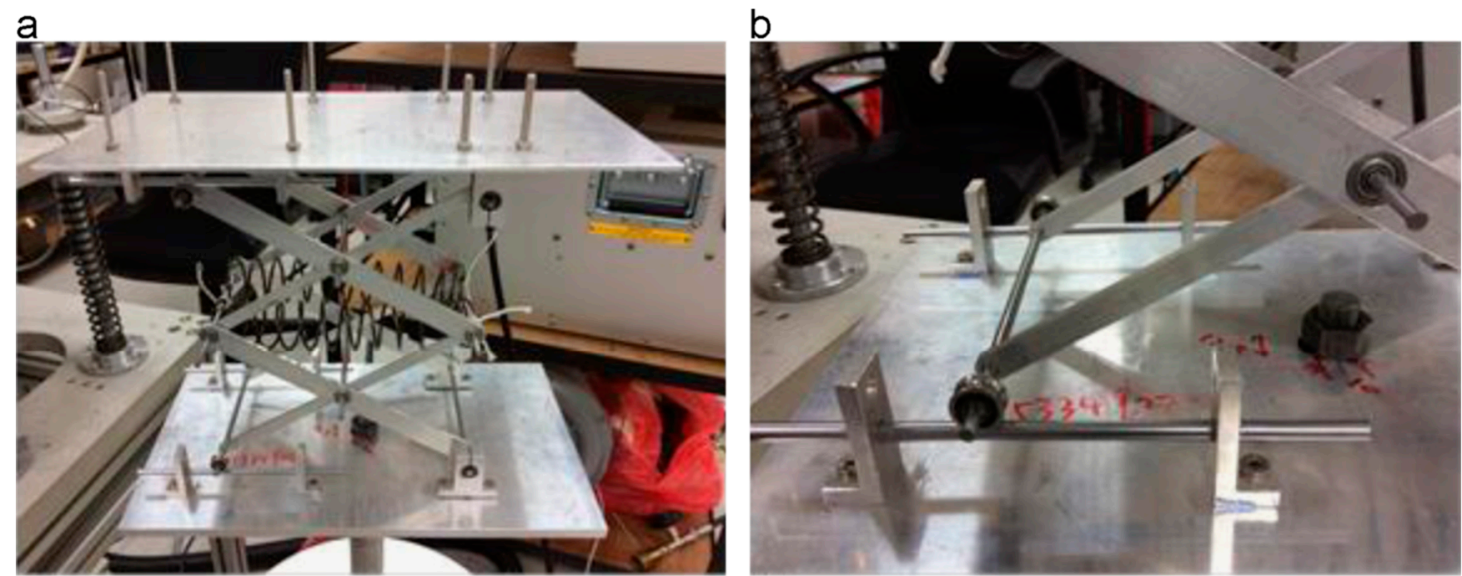

Figure 4. The prototype of the $x$-shaped vibration isolation system by Xiuting [53]; (a) prototype of the x-shaped; (b) Horizontal slide.

There is a new system that has been presented by Feng [65] where a unique human body-inspired passive vibration isolation system was developed with a special design of the coupled nonlinear inertia. This isolator is inspired by the anti-vibration structures of the nonlinear inertia, including a compact X-shaped structure. A horizontally mounted spring system that simulates the function of the legs and muscles, and a compact rotating unit that mimics arm swing or muscle stretching when walking represents flexion exercise. This new human body-inspired anti-vibration structure with nonlinear inertial coupling (HBIAVS-NI) system has adjustable structural parameters including nonlinear stiffness, nonlinear damping, and nonlinear inertia, which are designable nonlinear properties including the quasi-zero stiffness. In addition, nonlinear damping can reduce the jumping phenomenon. This method of providing nonlinear inertia brings several benefits to passive vibration control. First, the system has an even smaller peak transmissibility value at the ultra-low resonant frequency. Furthermore, the system presents a special nonlinear conservative force. The structure is more beneficial than that directly using a spring and damper. However, according to the experimental measurement results, the peak value of the displacement transmissibility of the HBIAVS-NI system is above 20 at around $1 \mathrm{~Hz}$ and is still larger than that of the Stewart platform and X-shaped support legs presented by Xiuting [47], which is 4 at $0.35 \mathrm{~Hz}$. Figure 5 shows the HBIAVS-NI prototype structure.
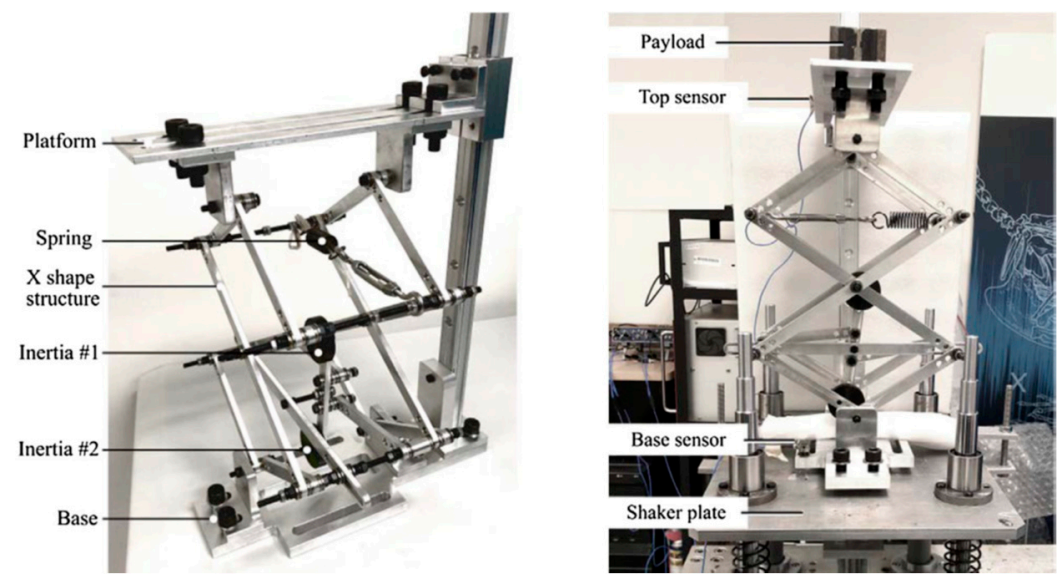

Figure 5. New human body-inspired anti-vibration structure with nonlinear inertial coupling (HBIAVS-NI) prototype structure [60].

Jiaxi [61] presented another component as a vibration isolator by using the QZS strut unit, which is shown in Figure 6. The schematic diagram of the QZS strut unit for static analysis is shown in 
Figure 7 [61] where the strut is at a static equilibrium position under a payload $F_{p}$, as shown in Figure 7a. The rod moves along the axis with a displacement $x$ under an additional force $f$ applied on the strut, as shown in Figure $7 \mathrm{~b}$. The advantage of the strut unit is to reduce the jumping phenomenon. The jumping phenomenon is suppressed effectively by increasing damping. There is an interaction force $f_{0}$ between the roller and the cam, and the angle between the interaction force and bar is $\theta$, as shown in Figure 7c.
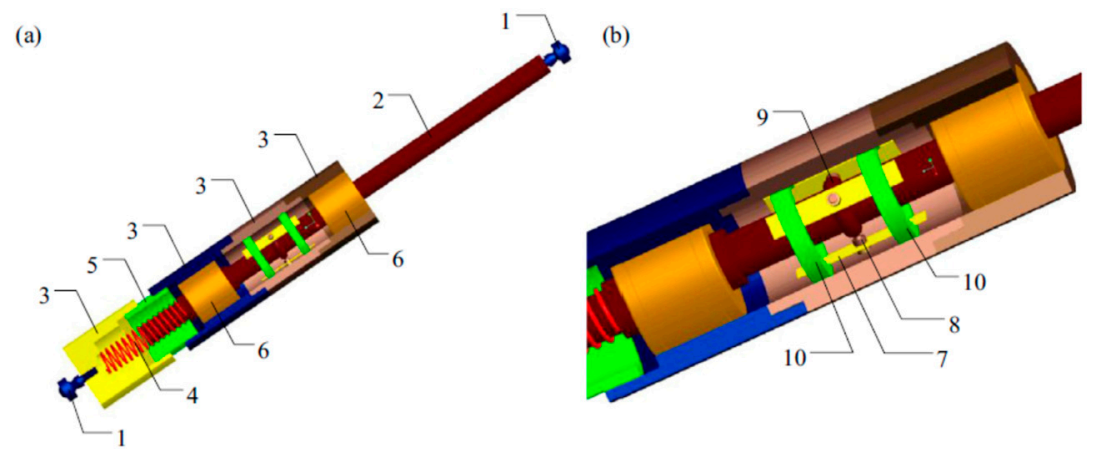

Figure 6. Schematic diagram of the quasi-zero stiffness (QZS) strut unit (a) Internal configuration; (b) a partially enlarged view [61].

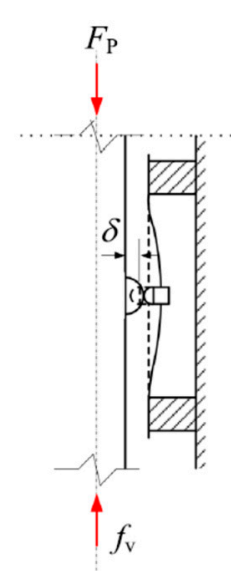

(a)

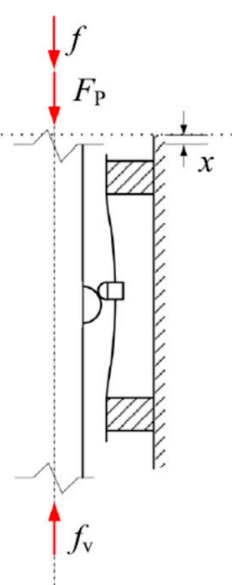

(b)
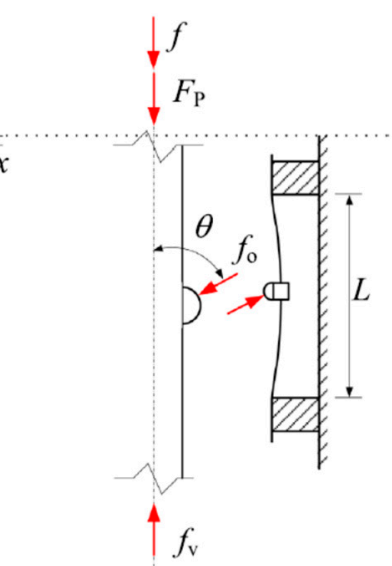

(c)

Figure 7. Schematic diagram of static analysis. (a) Static equilibrium position; (b) a compression $x$ under an external force $f$ load; (c) forces applied on the rod and the flexible beam. [61].

Although the isolator system has been applied in many real engineering applications, the QZS struts [48] have not been applied in a 6-DOF platform for the seating suspension design where the QZS characteristics are applied in all the six DOFs for extending the bandwidth of the vibration isolation into lower frequencies and improving the effectiveness of the isolator system. There are only simulations and a lack of experimental validation for the vibration isolator system, because the 6-DOF platform may require much packaging space, which is the bottleneck for the seating suspension system design.

Another method presented by Jiaxi [58] is to use a QZS torsional vibration isolator, as shown in Figure 8, where the isolation performance of the QZS torsional vibration isolator is sensitive to the difference in the actual output torque and design torque load, as this deviation can significantly reduce isolation performance. The QZS torsional vibration isolator is suitable for the applications where the transmission torque remains unchanged. As the isolator has a complex structure and many components, it has a limited application range where the designed transmission torque is constant. The vibration isolator system cannot be applied for the seating suspension design, because the vibration isolator system works only in the torsional/rotational direction. In addition, the system may experience 
the jumping phenomenon due to the lack of a damper. There were only simulation results and no experimental validation for the vibration isolator system.

(a)

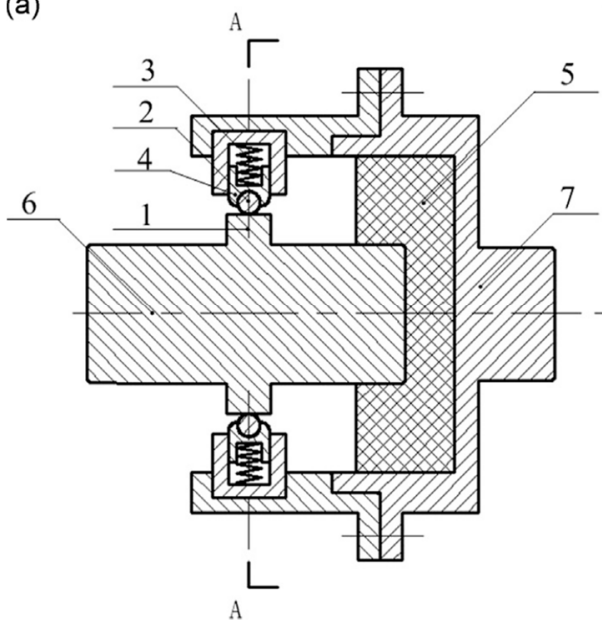

(b)

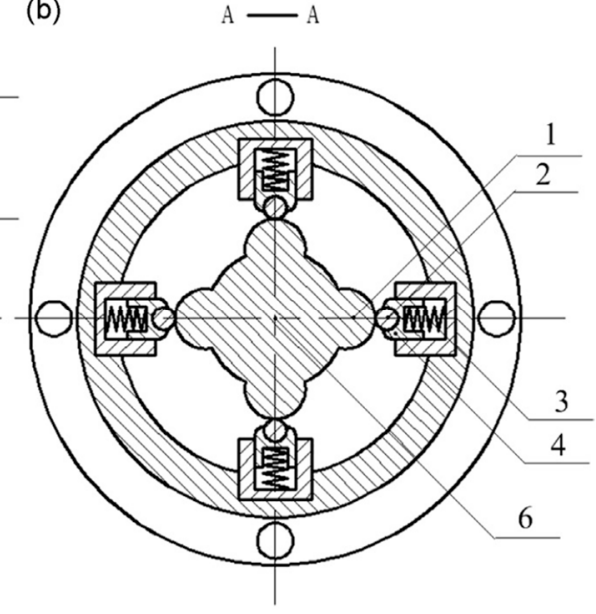

Figure 8. Schematic diagram of the QZS torsional vibration isolator. (a) Longitudinal-sectional view of the assembly, (b) cross-sectional view. Labels: 1-cam with radius $r_{2}, 2$-roller with radius $r_{1}, 3$-spring, 4-slider, 5-vulcanized rubber cam, 5-cylinder roller, 6-left shaft connector, 7-right shaft connector [58].

Guangxu [62] has presented a multi-direction vibration isolator of the high-static-low-dynamic stiffness (HSLDS) struts, the schematic diagram of which is shown in Figure 9. Figure 9a shows the static equilibrium position; Figure $9 \mathrm{~b}$ shows the base excitations $\mathrm{x} 0(\mathrm{t}), \mathrm{y} 0(\mathrm{t})$, and $\mathrm{z} 0(\mathrm{t})$ applied to the isolator; Figure $9 \mathrm{c}$ shows the equivalent mechanical model of the isolator. The proposed multi-direction vibration isolator can possess the HSLDS characteristics in the vertical direction and quasi-zero stiffness in two horizontal directions. Besides, the low-frequency isolation bandwidth can also be extended for each of the three directions, and there is no resonance phenomenon occurring in the two horizontal directions. For the vibration in the vertical direction, only one resonance peak has been shown near $4.35 \mathrm{~Hz}$, and there are no other resonance peaks that can be observed. Therefore, the suspension isolation system can be considered a good system. However, the system has a complex structure with many components and requires large packaging space. There are only simulation results and no experimental validation for the vibration isolator system. Xiaojie [64] presented a HSLDS vibration isolator system that provides excellent micro-vibration isolation performance at low frequencies. As the isolator system works under a micro-vibration environment, the maximum response amplitude is limited. The vibration displacement response amplitudes could also be limited due to the limited installation space.

Zheng $[60,66]$ presented two negative-stiffness magnetic spring (NSMS) vibration isolators. The first proposed NSMS vibration isolator, as shown in Figure 10a, can effectively reduce the peak transmissibility at the resonance frequency, but the jump-down frequency would increase under the excessive base excitation. The second proposed NSMS Stewart platform vibration isolator, as shown in Figure 11, has lower resonant frequencies. Hence, it has better isolation performance in the low-frequency range. The presented compact configuration of the NSMS isolator makes it a good candidate to be applied in the Stewart platform. 

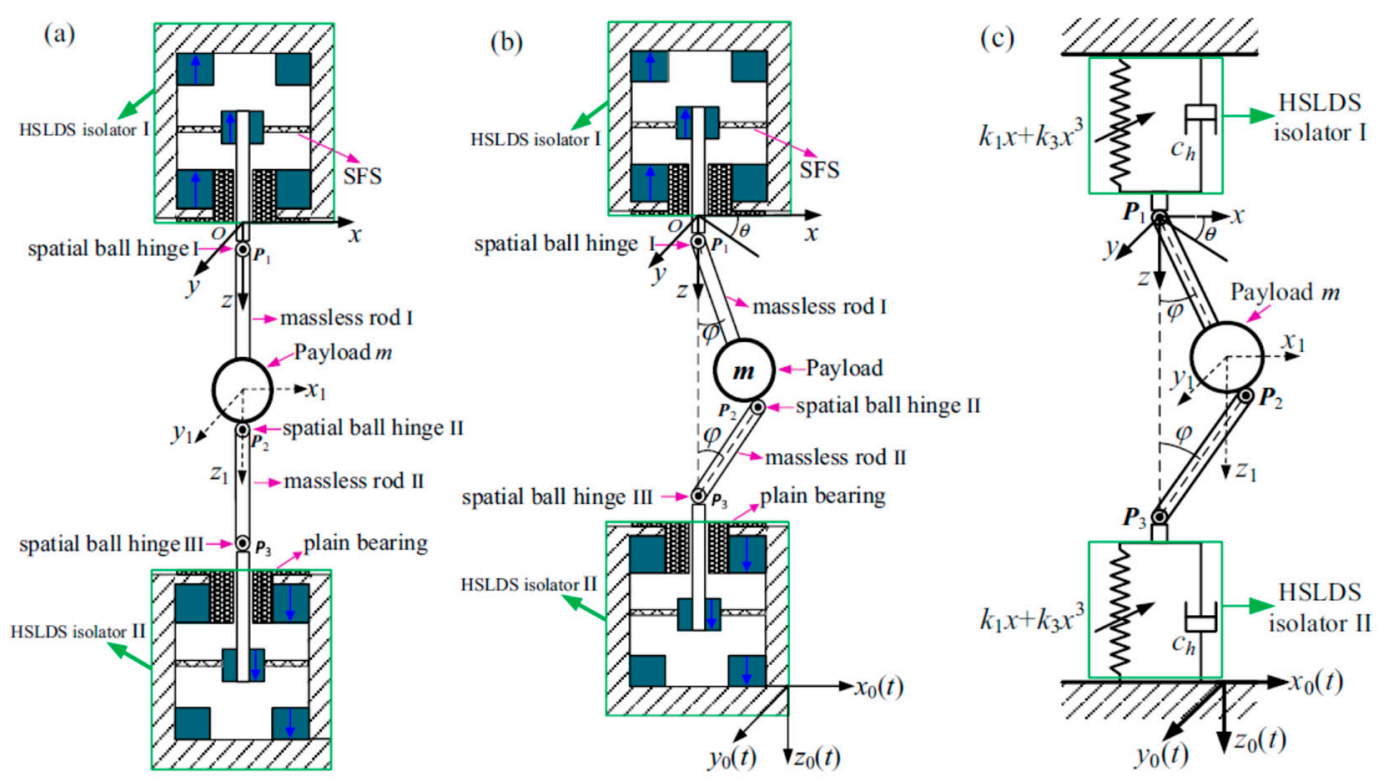

Figure 9. Schematic diagram of the multi-direction vibration isolator (a) shows the static equilibrium position; (b) shows the base excitations $\mathrm{x} 0(\mathrm{t}), \mathrm{y} 0(\mathrm{t})$, and $\mathrm{z} 0(\mathrm{t})$ applied to the isolator; (c) shows the equivalent mechanical model of the isolator [62].

(a)

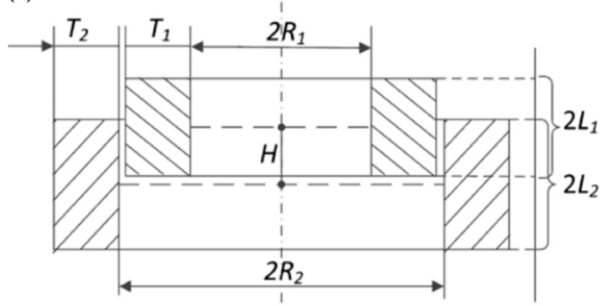

(b)

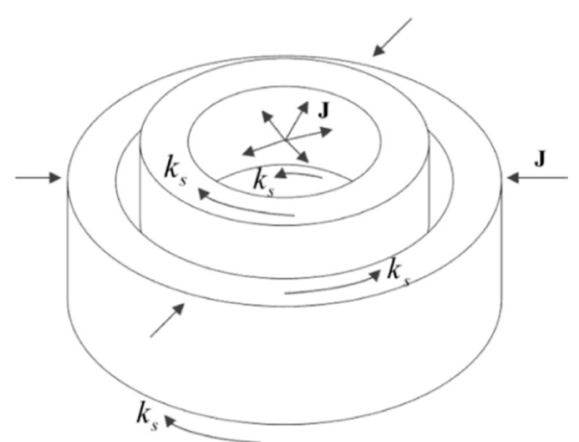

Figure 10. Schematic diagram of the first proposed negative-stiffness magnetic spring (NSMS) vibration isolator: (a) Geometric parameters of the first NSMS vibration isolator and (b) distribution of equivalent current on the first proposed NSMS vibration isolator [60].

Dong [42] presented a passive vibration isolator by combining the NSMS with a spiral flexure spring (SFS). The isolator provides good high-static-low-dynamic stiffness. The NSMS is employed to lower the resonant frequency and improve the damping property. The spiral flexure spring can provide a high load capacity under a small static deformation. According to their experimental results, the peak value of the displacement transmissibility is around 2.6 at $6 \mathrm{~Hz}$. 


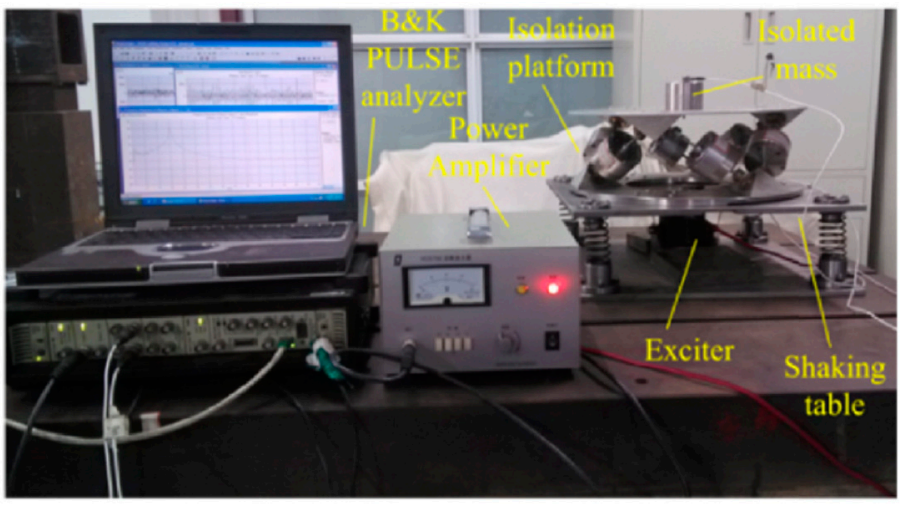

Figure 11. The second proposed NSMS Stewart platform vibration isolator prototype [66].

\section{Identified Research Gaps, Issues, and New Directions}

\subsection{Research Gaps and New Directions}

One of the good ideas for absorbing impact energy is to use negative Poisson's ratio (NPR) structures. One of the NPR structure cells is shown in Figure 12. If the inner cell structure of a future seat cushion is properly designed to be similar to the structure cell shown in Figure 13, the low-frequency vibration and impact energy of the seating suspension system will be absorbed and reduced, and the seat ride comfort will be improved.

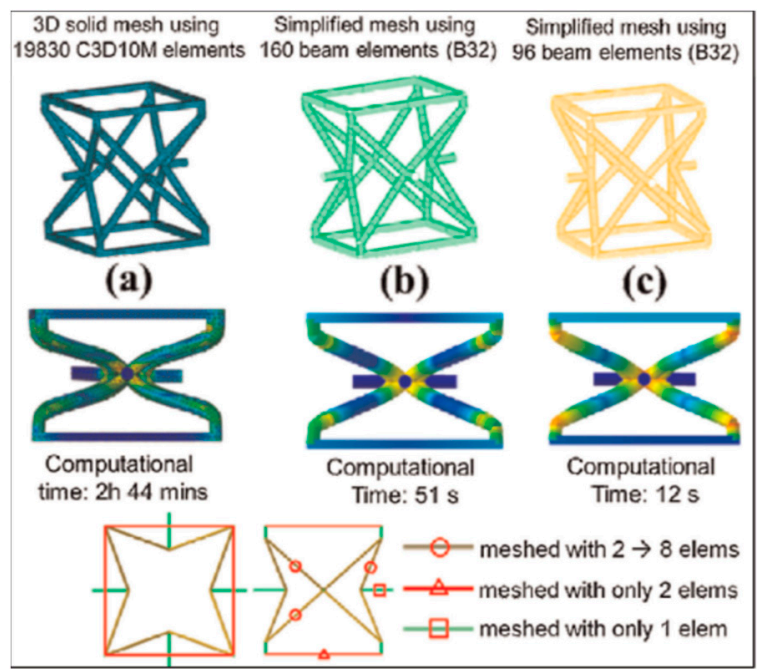

Figure 12. Modelling approaches of the 3D re-entrant cell. (a) 3D solid mesh using 19830 C3D10M elements, (b) simplified mesh using 160 beam elements, (c) simplified mesh using 96 beam elements [67].

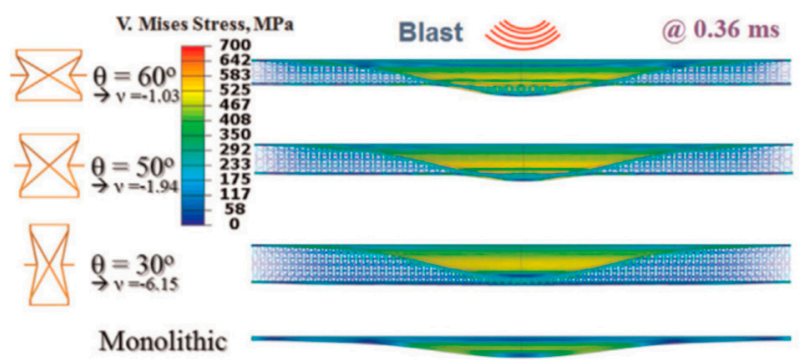

Figure 13. The blast absorbing structure of the negative Poisson's ratio cell [68]. 
If the double-diamond structure isolator is proved to be a good isolator or to have very small vibration transmissibility, it should be used as one of the cells/units/elements of the 3D-printed seat cushion structure. If the conventional passive seating suspension system added with the 3D-printed seat cushion is able to reduce the vibration transmissibility of the seating suspension system, the new system will be superior to the active and semi-active seating suspension system in terms of the cost and implementation readiness.

Very little research work has been conducted on a 3D-printed seating cushion built with the QZS or NPR cell/unit/element structure such as the double-diamond isolator element structure for reducing vibration transmissibility and improving ride comfort. Therefore, the seating suspension system integrated with a 3D-printed seat cushion, which consists of a QZS or NPR unit/element structure for vibration control, is identified as the research gap. The study of the 3D-printed seat cushion built with the QZS or NPR unit/element structure for vibration isolation is a new research area or direction to be focused on.

\subsection{Research Questions}

The following research questions have been raised from the above-identified research gaps and directions:

1. How can the QZS or NPR cell/unit/element structure be adopted to design a QZS or NPR seat cushion?

2. How will a 3D-printed QZS or NPR seat cushion be designed to reduce the peak vibration transmissibility and to improve the ride comfort?

3. If the QZS or NPR seat cushion can reduce the peak vibration transmissibility, will it also work within a whole car model?

\subsection{Aim of the Research}

The research aims to develop an innovative 3-D printed QZS or NPR seat cushion to be added in the seating suspension system and its analytical method to improve the ride comfort and safety of the vehicles' drivers. Furthermore, the research aims to alleviate the harmful and damaging effects of the transmitted vibration on the human body through investigating the passive seating suspension system and its vibration control method.

Moreover, the research aims to find the best choice for reducing the transmitted vibration and providing the best ride comfort. The research reviews the latest research in the area, including studying different vibration isolators and modelling the biodynamic response of the seated human body to vibrations. In addition, the research will evaluate the suitability of the proposed seat vibration control system in various vehicles such as trucks, cars, and agricultural vehicles in different operating conditions.

\section{Our Current Work and Contributions}

Based on the literature review, there are two vibration isolation systems proposed by Wu et al. [46] and by Sun et al. [50] where a scissors-like structure (SLS) is used to provide the QZS characteristics. The designs have met the vibration isolation performance criteria well because the passive vibration isolators are able to attenuate the vibrations from multiple directions.

The scissor-like structure as a support leg introduces nonlinearity, which helps to achieve a trade-off between the load capacity and vibration isolation performance. The most important feature of the scissor-like structure is that it can attenuate the vibrations of the $6 \mathrm{DOFs}$, which has been verified by the results in [46].

Our research aims to 3D-print a seat cushion mattress/structure. In order to investigate the vibration transmissibility of the seat cushion mattress/structure, the cell/unit/element structure of the 3D-printed seat cushion mattress has to be studied. A double-diamond structure (SLS supporting leg) is selected as the cell/unit/element structure of the 3D-printed seat cushion mattress. The double-diamond 
isolator structure (SLS supporting leg) supporting a mass is compared to a linear spring isolator structure supporting a mass for their vibration transmissibility using the analytical method and Adams simulation software model where the SLS supporting leg has the number of diamond structure elements of $n=2$, the diamond sidebar length of $L=80 \mathrm{~mm}$, and the assembly angle of $\theta=30^{\circ}$, as shown in Figure 14. The double-diamond isolator structure is selected as one of the cells or units of the seat cushion mattress/structure, which does not represent the whole seating suspension system. In order to further study the transmissibility ratio of the double-diamond isolator element structure, the analytical model will have to be developed. First, the kinematic energy of the system, the elastic potential energy of the spring deformation, and the friction dissipation energy of the joints are established. Second, the Lagrange principle is applied to develop the dynamic equation of the single-degree-of-freedom system where three complex nonlinear functions of the oscillator displacement related to the coefficients of the rotational inertia of the sidebars, the damping coefficients of the joints, and the stiffness coefficient of the spring have been established. Third, the three complex nonlinear functions of the oscillator displacement are calculated from the lateral displacement of the left- and right-hand-side joints and the relative rotational angle of the sidebars. The lateral displacement of the left- and right-hand-side joints and the relative rotational angle of the sidebars are functions of the oscillator displacement and are then expanded as a Taylor series of the first and second-order terms of the oscillator displacement where their coefficients are calculated from differentiating the geometric relationship of the double-diamond structure twice and the initial conditions of the structure. Fourth, the equation of motion is then simplified as a non-linear dynamic equation with the linear, squared, and cubic displacement terms. The non-linear dynamic equation can be solved and simulated through the Range-Kutta numerical integration method to obtain the vibration transmissibility ratio of the double-diamond isolator structure. The linear, squared, and cubic displacement terms can also be linearized to an equivalent linear displacement term. The vibration transmissibility ratio through the double-diamond isolator structure can be calculated from the Fourier transform and displacement frequency response function. The coefficient of the equivalent linear displacement term can be identified through matching the peak values of the vibration transmissibility ratios calculated from the Range-Kutta numerical integration method of the non-linear dynamic equation with those calculated from the Fourier transform and displacement frequency response function methods. Matlab codes have been developed to calculate the vibration transmissibility ratios using the Range-Kutta numerical integration of the non-linear dynamic equation and using the Fourier transform and displacement frequency response function. The linear spring vibration isolator is also analyzed for the vibration transmissibility using the Fourier transform and displacement frequency response function. The double-diamond and linear spring isolator structures are also simulated through Adams simulation software where their models are shown in Figure 14.

The transmissibility ratio for a conventional linear spring isolator element structure is calculated and plotted in the frequency range from 0.5 to $25 \mathrm{~Hz}$, as shown by the dashed curve in Figure 15.

It is seen from the solid and dashed curves in Figure 15 that the peak frequency and peak transmissibility ratio of the linear spring isolator structure supporting a mass model calculated by the analytical and ADAM simulation methods are the same where the peak natural resonant frequency is $13.78 \mathrm{~Hz}$ and the peak output response displacement amplitude is $66.54 \mathrm{~dB}$ (re 1 dimensionless). This result of ADAM simulation has verified the analytical model result, which means that both the analytical and ADAM simulation methods have been validated and can be applied to predict the transmissibility ratio of the double-diamond isolator structure, which will be illustrated below. 


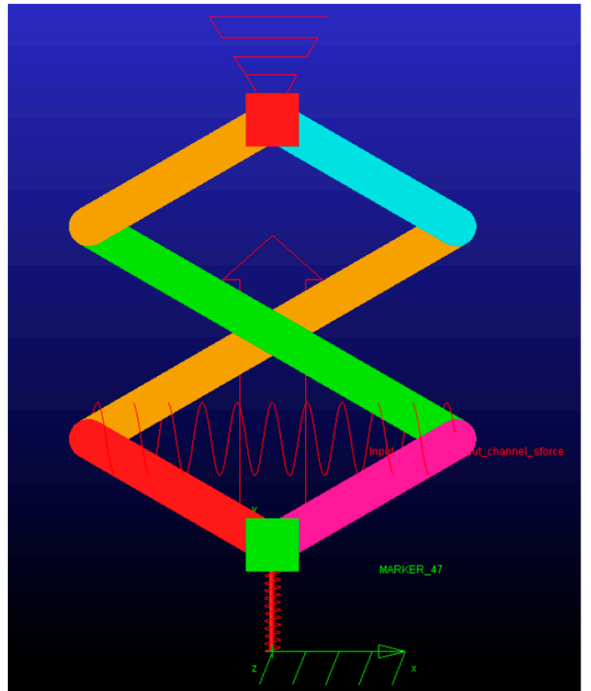

(a)

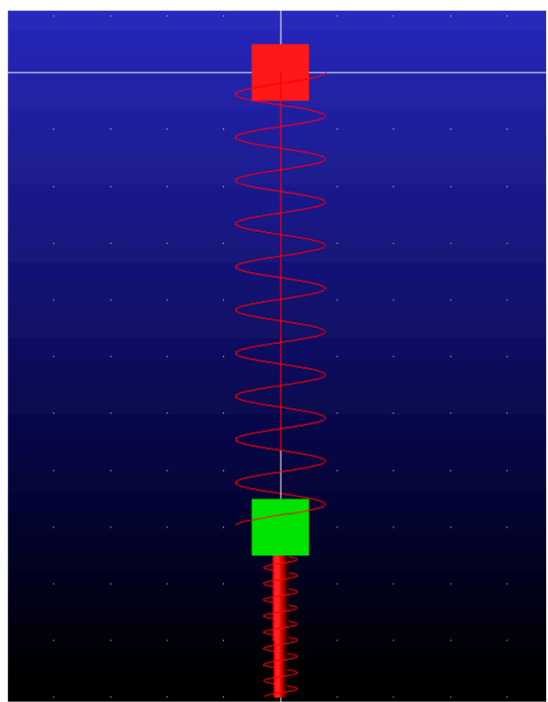

(b)

Figure 14. Adams simulation for the double-diamond isolator element structure (a) and linear spring isolator element structure (b).

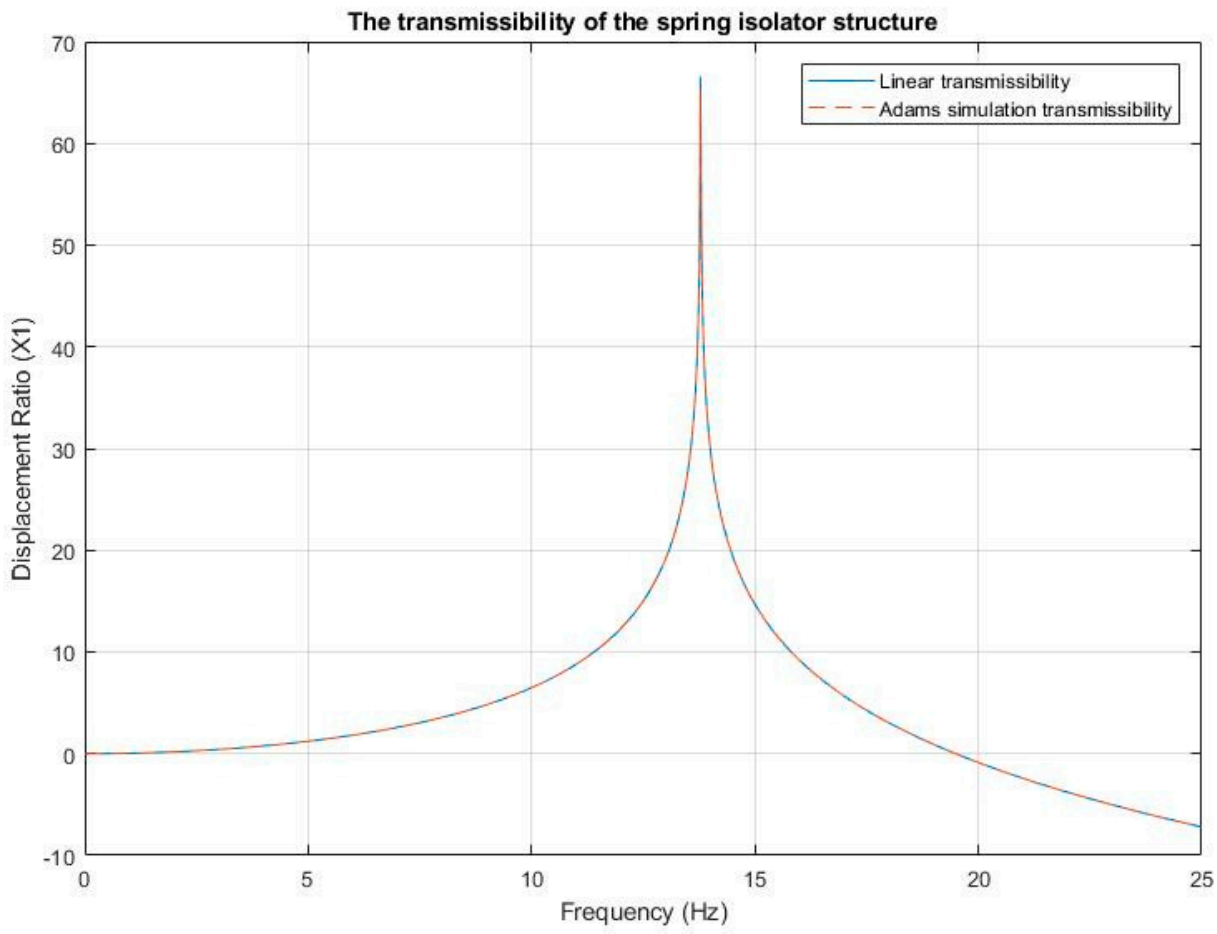

Figure 15. Comparison of transmissibility ratios of the linear spring isolator structure supporting a mass model calculated using analytical method with Matlab code.

The analytical and Matlab Simulink simulation results of vibration transmissibility ratios have been compared to the ADAMS simulation result for the double-diamond isolator structure supporting a mass model, which is given by Figure 16 .

It is seen from Figure 16 that the solid, dashed, and dot-dashed curves have very close peak frequencies and peak transmissibility ratios for the double-diamond isolator structure supporting a mass model calculated by the analytical and ADAM simulation methods where the peak natural 
resonant frequency is around $3.2 \mathrm{~Hz}$ and the peak displacement transmissibility ratio amplitude is $-1.11 \mathrm{~dB}$ (re 1 dimensionless). The analytical model has been validated by the ADAMS simulation result.

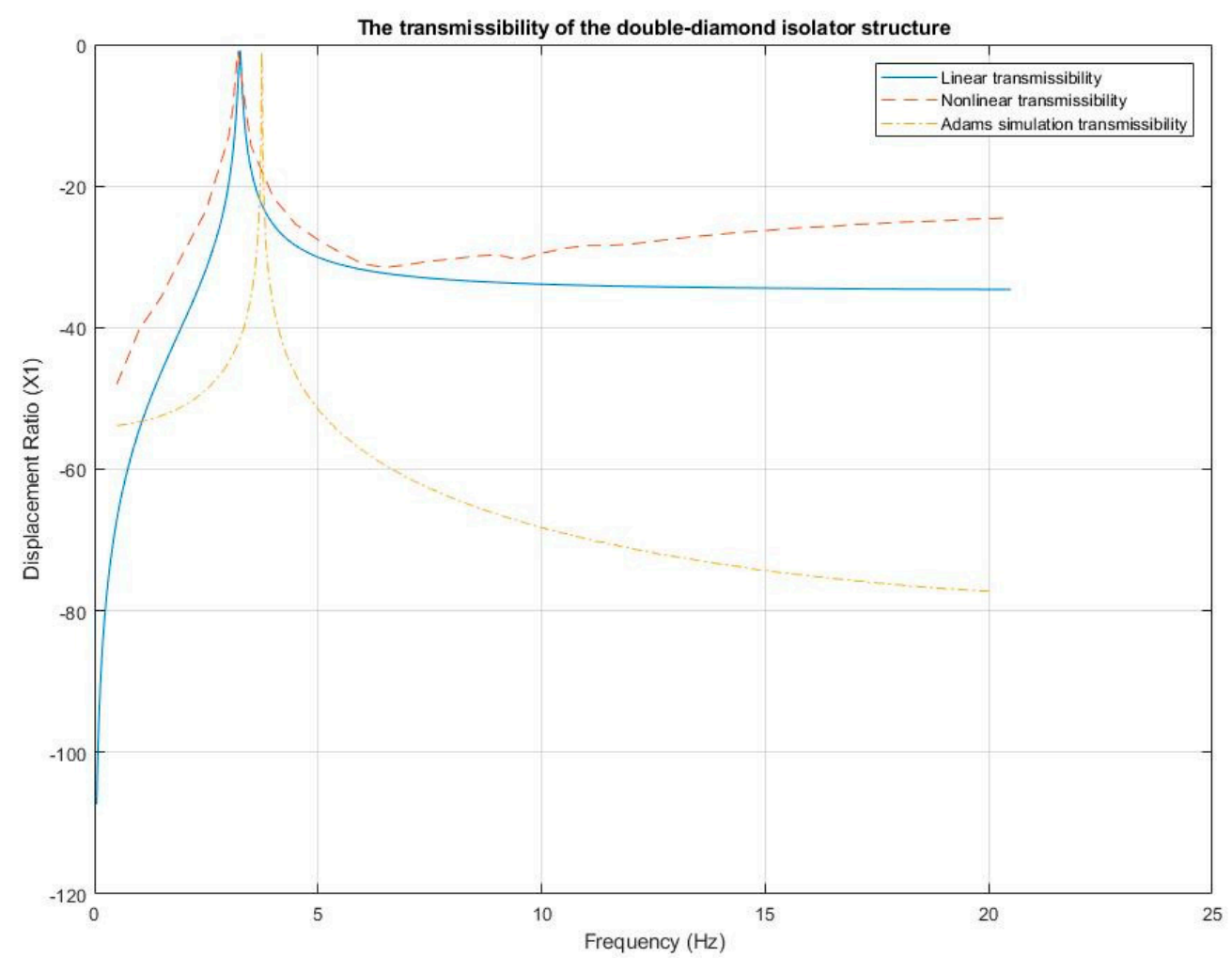

Figure 16. The transmissibility of the double-diamond isolator structure supporting a mass model using Adams simulation model and Matlab code.

It is seen from Figures 15 and 16 that the analytical results calculated from the Matlab codes have been verified by the results simulated from the Adams simulation software model for both the double-diamond and linear spring isolator structures. It has been confirmed that the peak transmissibility ratio of the double-diamond isolator structure is much lower than that of the linear spring isolator structure (peak value of $66.54 \mathrm{~dB}$ at $13.78 \mathrm{~Hz}$ for the linear spring-mass isolator and $1.11 \mathrm{~dB}$ at $3.2 \mathrm{~Hz}$ for the double-diamond isolator). Therefore, the double-diamond isolator structure is much better than the linear spring isolator for the peak transmissibility ratio and should be selected as the cell/unit/element structure of the 3D-printed seat cushion mattress. In the next stage, the geometric dimension and system parameters of the cell/unit/element structure of the 3D printed seat cushion mattress will be optimized for the lowest peak transmissibility ratio. The double-diamond isolator element structure will be cloned into multiple double-diamond isolator element structures to form a QZS or NPR seat cushion mattress that will be simulated using ADAMS or the ANSYS harmonic response module for its transmissibility performance. A prototype QZS or NPR seat cushion mattress will be designed and 3D-printed as test parts where the optimized double-diamond element structure will be selected for cells/units/elements of the 3D-printed prototype. If the QZS or NPR seat cushion is proven to work well for vibration attenuation, the third step is to prove that the QZS or NPR seat cushion is also able to reduce the vibration transmissibility in a whole vehicle suspension system model.

Our group has started working on the vibration control of seating systems since 2016 [16,69-72]. The major work was to identify the lumped mass-spring-dashpot model parameters of the combined driver and seat system in an IVECO truck (Acco 6x4 Euro 5 Dual Control). First, the vibration response was measured on a truck vehicle in the case of the air-conditioner being turned off at idle in neutral, and a one-dimensional simulation model was developed for the driver and seating system. The mass 
and stiffness coefficients were adjusted so that the calculated natural resonant frequencies coincided with the measured ones, and the damping coefficients were adjusted so that the calculated frequency response amplitude peak values coincided with the measured ones. The identified parameters were used for the design of vibration control of the driver and seating system. The PID, fuzzy PID, and state feedback H-infinity controllers were designed and applied to the active vibration control actuator of the seating suspension structure in $[16,70]$. An analysis of the parameter sensitivity of a 5-DOF model-based Monte Carlo simulation was performed [70]. The relevant active vibration control of the seating system was simulated in the Simulink software [70].

\section{Conclusions}

This review has presented the recent development of the different passive seating systems for commercial vehicles such as buses, trucks, and earth-moving vehicles with a focus on state-of-the-art passive vibration control systems. It is seen that designing a safe and comfortable seating system has become one of the main focuses of high-tech vehicle manufacturing companies.

This paper identifies the research gap and raises research questions in the area so that our research team are able to find novel solutions for a comfortable and ergonomic seating suspension system of commercial vehicles, that is, to add a novel 3-D-printed QZS or NPR seat cushion in a conventional passive seating suspension system. The passive vibration control system generally costs less, and its relative simplicity makes it more reliable and easier to implement.

The analytical and simulation models of the double-diamond isolator structure have been developed and validated to predict the vibration transmissibility for the element/unit/cell of the proposed seat cushion mattress. The transmissibility ratios of the double-diamond and conventional linear spring isolator structure have been compared.

The double-diamond isolator structure has been proven to be much better than a conventional linear spring isolator element structure for vibration isolation. The dimension and parameters of the double-diamond isolator structure will be optimized for the lowest peak vibration transmissibility.

The seat cushion mattress consisting of the optimized double-diamond isolator cell/unit/element structure will be 3D-printed and evaluated for its vibration isolation performance in the whole vehicle and seating suspension system in our future work.

Author Contributions: L.G. analyzed the data; L.G. and X.W. contributed materials/analysis tools; L.G., X.W. R.-L.F. and F.B. wrote the paper. All authors have read and agreed to the published version of the manuscript.

Funding: This research was funded by Australian Research Council Linkage Project LP160100273.

Conflicts of Interest: The authors declare no conflict of interest.

\section{References}

1. Mabbott, N.; Foster, G.; McPhee, B. Heavy Vehicle Seat Vibration and Driver Fatigue; Australian Transport Safety Bureau: Canberra, Australia, 2002; Volume 203.

2. Nadalin, V.; Kreiger, N.; Parent, M.-E.; Salmoni, A.; Sass-Kortsak, A.; Siemiatycki, J.; Sloan, M.; Purdham, J. Prostate cancer and occupati:nal whole-body vibration exposure. Ann. Occup. Hyg. 2012, 56, 968-974. [CrossRef] [PubMed]

3. Bovenzi, M.; Hulshof, C.T.J. An updated review of epidemiologic studies on the relationship between exposure to whole-body vibration and low back pain (1986-1997). Int. Arch. Occup. Environ. Health 1999, 72, 351-365. [CrossRef] [PubMed]

4. McPhee, B.; Foster, G.; Long, L. Bad Vibrations: A Handbook on Whole-Body Vibration Exposure in Mining; Coal Serv. Health Safety Trust, Queensland Min. Safety: Sydney, NSW, Australia, 2009.

5. Newell, G.S.; Mansfield, N.J. Evaluation of reaction time performance and subjective workload during whole-body vibration exposure while seated in upright and twisted postures with and without armrests. Int. J. Ind. Ergon. 2008, 38, 499-508. [CrossRef]

6. Özkaya, N.; Goldsheyder, D.; Willems, B. Effect of operator seat design on vibration exposure. Am. Ind. Hyg. Assoc. J. 1996, 57, 837-842. [CrossRef] 
7. Beranek, L.L.; Ver, I.L. Noise and vibration control engineering principles and applications. In Noise and Vibration Control Engineering Principles and Applications; John Wiley \& Sons, Inc.: Hoboken, NJ, USA, 1992; 814p.

8. Mitra, A.C.; Desai, G.J.; Patwardhan, S.R.; Shirke, P.H.; Kurne, W.M.H.; Banerjee, N. Optimization of passive vehicle suspension system by genetic algorithm. Procedia Eng. 2016, 144, 1158-1166. [CrossRef]

9. Mead, D.J.; Meador, D.J. Passive Vibration Control; Wiley: Chichester, UK, 1998.

10. Franchek, M.A.; Ryan, M.W.; Bernhard, R.J. Adaptive passive vibration control. J. Sound Vib. 1996, 189, 565-585. [CrossRef]

11. Karnopp, D.; Crosby, M.J.; Harwood, R.A. Vibration control using semi-active force generators. J. Eng. Ind. 1974, 96, 619-626. [CrossRef]

12. Fuller, C.C.; Elliott, S.; Nelson, P.A. Active Control of Vibration; Academic Press: Cambridge, MA, USA, 1996.

13. Karnopp, D. Active and semi-active vibration isolation. In Current Advances in Mechanical Design and Production VI. Pergamon; ASME: New York, NY, USA, 1995; pp. 409-423.

14. Denoyer, K.K.; Johnson, C.D. Recent achievements in vibration isolation systems for space launch and on-orbit applications. In Proceedings of the 52nd IAF, International Astronautical Congress, Toulouse, France, 1-5 October 2001.

15. Sun, W.; Gao, H.; Kaynak, O. Adaptive backstepping control for active suspension systems with hard constraints. IEEE/ASME Trans. Mechatron. 2012, 18, 1072-1079. [CrossRef]

16. Ning, D.; Sun, S.; Zhang, J.; Du, H.; Li, W.; Wang, X. An active seat suspension design for vibration control of heavy-duty vehicles. J. Low Freq. Noise Vib. Act. Control 2016, 35, 264-278. [CrossRef]

17. Alanoly, J.; Sankar, S. A new concept in semi-active vibration isolation. J. Mech. Transm. Autom. Des. 1987, 109, 242-247. [CrossRef]

18. Liu, Y.; Waters, T.P.; Brennan, M.J. A comparison of semi-active damping control strategies for vibration isolation of harmonic disturbances. J. Sound Vib. 2005, 280, 21-39. [CrossRef]

19. Ver, I.L.; Beranek, L.L. Noise and Vibration Control Engineering-Principles and Applications, Wiley, 2006: Noise and Vibration Control Engineering-Principles and Applications; Bukupedia: New York, NY, USA, 2006.

20. Zhou, N.; Liu, K. A tunable high-static-low-dynamic stiffness vibration isolator. J. Sound Vib. 2010, 329, 1254-1273. [CrossRef]

21. Mayton, A.G.; DuCarme, J.P.; Jobes, C.C.; Matty, T.J. Laboratory Investigation of Seat Suspension Performance during Vibration Testing. In Proceedings of the ASME 2006 International Mechanical Engineering Congress and Exposition. American Society of Mechanical Engineers, Chicago, IL, USA, 5-10 November 2006; pp. 177-183.

22. Jalili, N. A comparative study and analysis of semi-active vibration-control systems. J. Vib. Acoust. 2002, 124, 593-605. [CrossRef]

23. Platus, D.L. Negative-stiffness-mechanism vibration isolation systems. In Proceedings of the Vibration Control in Microelectronics, Optics, and Metrology. International Society for Optics and Photonics, San Jose, CA, USA, 1 February 1992; Volume 1619, pp. 44-55.

24. Maciejewski, I.; Meyer, L.; Krzyzynski, T. Modelling and multi-criteria optimisation of passive seat suspension vibro-isolating properties. J. Sound Vib. 2009, 324, 520-538. [CrossRef]

25. Ning, D.; Du, H.; Sun, S.; Li, W.; Zhang, B. An innovative two-layer multiple-DOF seat suspension for vehicle whole-body vibration control. IEEE/ASME Trans. Mechatron. 2018, 23, 1787-1799. [CrossRef]

26. Zhang, L.; Helander, M.G.; Drury, C.G. Identifying factors of comfort and discomfort in sitting. Hum. Factors 1996, 38, 377-389. [CrossRef]

27. Andersson, B.J.G.; Ortengren, R.; Nachemson, A.; Elfstrom, G. Lumbar disc pressure and myoelectric back muscle activity during sitting.IV. Studies on a car driver's seat. Scand. J. Rehab. Med. 1974, 6, 128-133.

28. Ebe, K.; Griffin, M.J. Qualitative models of seat discomfort including static and dynamic factors. Ergonomics 2000, 43, 771-790. [CrossRef]

29. Kamijo, K.; Tsujimura, H.; Obara, H.; Katsumata, M. Evaluation of Seating Comfort; Technical Paper No. 820761; Society of Automotive Engineers, Inc.: Warrendale, PA, USA, 1982.

30. Hertzberg, H.T.E. The Human Buttocks in Sitting: Pressures, Patterns, and Palliatives; Technical Paper No.72005; Society of Automotive Engineers, Inc.: New York, NY, USA, 1972. 
31. Diebschlag, W.; Heidinger, F.; Kuurz, B.; Heiberger, R. Recommendation for Ergonomic and Climatic Physiological Vehicle Seat Design; Technical Paper No.880055; Society of Automotive Engineers, Inc.: Warrendale, PA, USA, 1988.

32. Levrat, E.; Voisin, A.; Bombardier, S.; Brémont, J. Subjective evaluation of car seat comfort with fuzzy set techniques. Int. J. Intell. Syst. 1997, 12, 891-913. [CrossRef]

33. Coyte, J.L.; Stirling, D.; Du, H.; Ros, M. Seated whole-body vibration analysis, technologies, and modeling: A survey. IEEE Trans. Syst. Man Cybern. Syst. 2015, 46, 725-739. [CrossRef]

34. Picu, L.; Picu, M.; Rusu, E.V.C. Evaluation of Human Exposure to Whole-Body Vibration Verification Method of Stevens's Power Law. In Proceedings of the 18th International Multidisciplinary Scientific Geo Conference, Albena, Bulgaria, 30 June-9 July 2018.

35. Mechanical Vibration and Shock-Evaluation of Human Exposure to Whole-Body Vibration-Part 1: General Requirements; ISO Standard 2631-1; International Organization for Standardization (ISO): Geneva, Switzerland, 1997.

36. Mechanical Vibration and Shock. Evaluation of Human Exposure to Whole-Body Vibration. General Requirements; BS ISO 2631-1; BSI: London, UK, 1997.

37. Giaime, J.; Saha, P.; Shoemaker, D. A passive vibration isolation stack for LIGO: Design, modeling, and testing. Rev. Sci. Instrum. 1996, 67, 208-214. [CrossRef]

38. Friswell, M.I.; Flores, E.I.S.; Xia, Y. Vibration isolation using nonlinear springs. Proc. ISMA2012-USD 2012, 2012, 2333-2342.

39. Carrella, A.; Brennan, M.J.; Waters, T.P. Static analysis of a passive vibration isolator with quasi-zero-stiffness characteristic. J. Sound Vib. 2007, 301, 678-689. [CrossRef]

40. Le, T.D.; Ahn, K.K. A vibration isolation system in low frequency excitation region using negative stiffness structure for vehicle seat. J. Sound Vib. 2011, 330, 6311-6335. [CrossRef]

41. Holtz, M.W.; Van Niekerk, J.L. Modelling and design of a novel air-spring for a suspension seat. J. Sound Vib. 2010, 329, 4354-4366. [CrossRef]

42. Valeev, A.; Zotov, A.; Kharisov, S. Designing of compact low frequency vibration isolator with quasi-zero-stiffness. J. Low Freq. Noise Vib. Act. Control 2015, 34, 459-473. [CrossRef]

43. Xu, D.; Zhang, Y.; Zhou, J.; Lou, J. On the analytical and experimental assessment of the performance of a quasi-zero-stiffness isolator. J. Vib. Control 2014, 20, 2314-2325. [CrossRef]

44. Gan, Z.; Hillis, A.J.; Darling, J. Adaptive control of an active seat for occupant vibration reduction. J. Sound Vib. 2015, 349, 39-55. [CrossRef]

45. Earnshaw, S. On the nature of the molecular forces which regulate the constitution of the luminferous ether. Trans. Camb. Phil. Soc. 1842, 7,97-112.

46. Van der Westhuizen, A.; van Niekerk, J.L. Verification of seat effective amplitude transmissibility (SEAT) value as a reliable metric to predict dynamic seat comfort. J. Sound Vib. 2006, 295, 1060-1075. [CrossRef]

47. Sun, X.; Jing, X. Analysis and design of a nonlinear stiffness and damping system with a scissor-like structure. Mech. Syst. Signal Process. 2016, 66, 723-742. [CrossRef]

48. Le, T.D.; Ahn, K.K. Experimental investigation of a vibration isolation system using negative stiffness structure. Int. J. Mech. Sci. 2013, 70, 99-112. [CrossRef]

49. Sun, X.; Jing, X. Multi-direction vibration isolation with quasi-zero stiffness by employing geometrical nonlinearity. Mech. Syst. Signal Process. 2015, 62-63, 149-163. [CrossRef]

50. Alabuzhev, P.M. Vibration Protection and Measuring Systems with Quasi-Zero Stiffness; CRC Press: Boca Raton, FL, USA, 1989.

51. Lan, C.C.; Yang, S.A.; Wu, Y.S. Design and experiment of a compact quasi-zero-stiffness isolator capable of a wide range of loads. J. Sound Vib. 2014, 333, 4843-4858. [CrossRef]

52. Ibrahim, R.A. Recent advances in nonlinear passive vibration isolators. J. Sound Vib. 2008, 314, 371-452. [CrossRef]

53. Molyneux, W.G. The support of an aircraft for ground resonance tests: A survey of available methods. Aircr. Eng. Aerosp. Technol. 1958, 30, 160-166. [CrossRef]

54. Xu, D.; Yu, Q.; Zhou, J.; Bishop, S.R. Theoretical and experimental analyses of a nonlinear magnetic vibration isolator with quasi-zero-stiffness characteristic. J. Sound Vib. 2013, 332, 3377-3389. [CrossRef]

55. Zhou, J.; Wang, X.; Xu, D.; Bishop, S. Nonlinear dynamic characteristics of a quasi-zero stiffness vibration isolator with cam-roller-spring mechanisms. J. Sound Vib. 2015, 346, 53-69. [CrossRef] 
56. Kovacic, I.; Brennan, M.J.; Waters, T.P. A study of a nonlinear vibration isolator with a quasi-zero stiffness characteristic. J. Sound Vib. 2008, 315, 700-711. [CrossRef]

57. Carrella, A.; Brennan, M.J.; Kovacic, I.; Waters, T.P. On the force transmissibility of a vibration isolator with quasi-zero-stiffness. J. Sound Vib. 2009, 322, 707-717. [CrossRef]

58. Zhou, J.; Xu, D.; Bishop, S. A torsion quasi-zero stiffness vibration isolator. J. Sound Vib. 2015, 338, 121-133. [CrossRef]

59. Li, Q.; Zhu, Y.; Xu, D.; Hu, J.; Min, W.; Pang, L. A negative stiffness vibration isolator using magnetic spring combined with rubber membrane. J. Mech. Sci. Technol. 2013, 27, 813-824. [CrossRef]

60. Zheng, Y.; Zhang, X.; Luo, Y.; Yan, B.; Ma, C. Design and experiment of a high-static-low-dynamic stiffness isolator using a negative stiffness magnetic spring. J. Sound Vib. 2016, 360, 31-52. [CrossRef]

61. Zhou, J.; Xiao, Q.; Xu, D.; Ouyang, H.; Li, Y. A novel quasi-zero-stiffness strut and its applications in six-degree-of-freedom vibration isolation platform. J. Sound Vib. 2017, 394, 59-74. [CrossRef]

62. Dong, G.; Zhang, X.; Luo, Y.; Zhang, Y.; Xie, S. Analytical study of the low frequency multi-direction isolator with high-static-low-dynamic stiffness struts and spatial pendulum. Mech. Syst. Signal Process. 2018, 110, 521-539. [CrossRef]

63. Dong, G.; Zhang, X.; Xie, S.; Yan, B.; Luo, Y. Simulated and experimental studies on a high-static-low-dynamic stiffness isolator using magnetic negative stiffness spring. Mech. Syst. Signal Process. 2017, 86, 188-203. [CrossRef]

64. Wang, X.; Liu, H.; Chen, Y.; Gao, P. Beneficial stiffness design of a high-static-low-dynamic-stiffness vibration isolator based on static and dynamic analysis. Int. J. Mech. Sci. 2018, 142, 235-244. [CrossRef]

65. Feng, X.; Jing, X.; Xu, Z.; Gao, Y. Bio-inspired anti-vibration with nonlinear inertia coupling. Mech. Syst. Signal Process. 2019, 124, 562-595. [CrossRef]

66. Zheng, Y.; Li, Q.; Yan, B.; Luo, Y.; Zhang, X. A Stewart isolator with high-static-low-dynamic stiffness struts based on negative stiffness magnetic springs. J. Sound Vib. 2018, 422, 390-408. [CrossRef]

67. Imbalzano, G.; Tran, P.; Ngo, T.D.; Lee, P.V.S. A numerical study of auxetic composite panels under blast loadings. Compos. Struct. 2016, 135, 339. [CrossRef]

68. Qiao, J.; Chen, C.Q. Analyses on the in-plane impact resistance of auxetic double arrowhead honeycombs. J. Appl. Mech. 2015, 82, 051007. [CrossRef]

69. Wang, X.; Bi, F.; Du, H. Reduction of low-frequency vibration of a truck driver and seating system through system parameter identification, sensitivity analysis, and active control. Mech. Syst. Signal Process. 2018, 105, 16-35. [CrossRef]

70. Heidarian, A. and Wang X. Review on Seat Suspension System Technology Development. Appl. Sci. 2019, 9, 2834. [CrossRef]

71. Zhao, Y.; Wang, X. A Review of Low-Frequency Active Vibration Control of Seat Suspension Systems. Appl. Sci. 2019, 9, 3326. [CrossRef]

72. Alashmoriand, M.; Wang, X. A Systematic Literature Review of Various Control Techniques for Active Seat Suspension Systems. Appl. Sci. 2020, 10, 1148. [CrossRef]

(C) 2020 by the authors. Licensee MDPI, Basel, Switzerland. This article is an open access article distributed under the terms and conditions of the Creative Commons Attribution (CC BY) license (http://creativecommons.org/licenses/by/4.0/). 